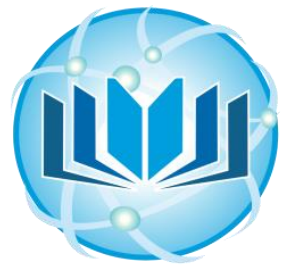
\title{
Writing a Personal Inventory as a Wakeful Suggestion
}

\section{Rivka A Edery*}

Affiliation: Master of Social Work (MSW), Fordham University Graduate School of Social Service, USA

*Corresponding author: Rivka A. Edery, Master of Social Work (MSW), Fordham University Graduate School of Social Service, USA, Tel: (361) 704-4051, E-mail: rebecca.edery@gmail.com

Citation: Edery RA. Writing a personal inventory as a wakeful suggestion (2019) Edelweiss Psyi Open Access 3: 1-3

Received: Dec 29, 2018

Accepted: Jan 03, 2019

Published: Jan 10, 2019

Copyright: $\odot 2019$ Edery RA., This is an open-access article distributed under the terms of the Creative Commons Attribution License, which permits unrestricted use, distribution, and reproduction in any medium, provided the original author and source are credited.

\section{Abstract}

Mental Health can be understood as the health of one's life's energy system. The field of psychology continues to provide valuable information, research and insight on the role and power of thought, both conscious and unconscious. Resentments, anger, and past hurts, not properly processed, contributes to depression, anxiety, stress, and a persistent sense of chronic loneliness in life. Specifically, relationships are the front lines in carrying the toll for one's unprocessed resentments, both in perpetuating the same hurts on to others, or tragically ending up as the victim. It is possible that by conducting a Personal Inventory, one can begin to have insight into their personal character and the system from which they operate. The information and patterns garnered from such an analysis, can readily offer the open-minded individual with inspiring new insights and required actions, regarding their relationship trajectory.

Keywords: Resentments, Psychology, Self-Assessment in psychotherapy, Character defects, Character inventory, Relationships.

\section{Introduction}

Resentment is a consequence of unfair, abusive treatment, and a perception of wrongdoing. It is also referred to as bitterness or hatred. Often resentments are fueled by feelings of disappointment, anger, rage, sadness, disgust, fear, pain, shame or shock, in regard to a particular incident(s). Resentments can form as a result of being taken advantage of, jealousy, envy, thoughtless acts, or engagement with a repeated harmful pattern. Sometimes these patterns are self-imposed in adulthood, where one unconsciously, or consciously, repeatedly seeks out the same underlying patterns of hurt, negativity, injustice or isolates themselves; in response to their personal unprocessed hurts. The resentment can feel like a perpetual unrest, a constant repetition of thoughts and feelings tied to the original hurtful event.

The possible benefit to writing out a resentment inventory is the letting go of the negative emotions, and a change of dysfunctional behavioral patterns that are a reflection of these wounds. It is well-known that negative emotions are harmful to your emotional health and can impact your quality of life. Writing out a resentment inventory may help you gain conscious awareness of your personal reality, or personal filter system. I define "personal reality" as your feelings, thoughts, behaviors, habits and beliefs. This conscious awareness is crucial because most of your life experiences are filtered through your personal reality. Bringing your personal filter system to the surface will enable you to effect long-term changes of conditions and resolve the causes of your problematic patterns. When writing a personal inventory, the patterns of how you reacted to resentments will help you understand your life on a much different level than you may have up to this point (Table 1).

\section{Set Aside Your 'Broken Tools'}

The purpose of a Personal Inventory (lists of your resentments, fears, sex conduct and review of harms other than sexual) is to help you

\begin{tabular}{|c|c|c|c|c|}
\hline Column 1 & Column 2 & Column 3 & Column 4 & Column 5 \\
\hline $\begin{array}{c}\text { Who or } \\
\text { What do I } \\
\text { fear? }\end{array}$ & $\begin{array}{c}\text { Why am I } \\
\text { afraid? }\end{array}$ & $\begin{array}{c}\text { Is this fear } \\
\text { based on } \\
\text { false or } \\
\text { true } \\
\text { informatio } \\
\text { n? }\end{array}$ & $\begin{array}{c}\text { What is it } \\
\text { that you } \\
\text { want } \\
\text { changed } \\
\text { about this } \\
\text { fear,that } \\
\text { you will } \\
\text { do } \\
\text { whatever } \\
\text { it } \\
\text { TAKES? }\end{array}$ & $\begin{array}{c}\text { What is } \\
\text { your new } \\
\text { plan of } \\
\text { action/inact } \\
\text { ion with } \\
\text { regards to } \\
\text { this fear? }\end{array}$ \\
\hline & & & & \\
\hline & & & & \\
\hline
\end{tabular}

identify what "broken tools" continue to have power over your life experiences. A personal inventory is not a self-blaming, shaming or critical self-analysis. It is not for the purposes of finding fault with yourself, but rather, an opportunity to inventory your personal toolbox, and upgrade to more functional tools. It entails a readiness to look within and address what changes will improve your life. For example, it is very easy to say: "I really want to stop this habit of lying to my spouse" (use your own examples), when in fact, you find it very hard to tell the truth. If you are not aware that it is hard for you to tell the truth, you will not be able to decide to change it. A Personal Inventory is a fact-finding, fact-facing, searching, detailed list that will disclose behavioral problems that are no longer serving you in your life. It details your personal "reality." To sort out what is harmful that you need to let go of, you need to carefully examine what is your personal reality. If you are not completely committed to the process of sorting out and discarding your personal obstructions, you will remain a victim 
of your own limiting beliefs, thoughts, feelings and habits. The goal when doing this inventory is to do it thoroughly and courageously.

\section{Writing a Personal Inventory: A Practical Guide}

A Personal Inventory consists of four "inventories":

1 - Resentments

2 - Fears

3 - Sex Conduct

4 - Harms done to others

Resentment is a re-feeling (think 're-sentiment') of anger whenever you think of something significant. I suggest that you start out with your most intense resentments and then proceed with the rest of your resentments. Divide a sheet of paper into five columns and label the columns as follows:

Column 1: Who or what am I resentful toward?

Column 2: What happened? (Or what did not happen, what did I not receive or what was taken from me?)

Column 3: Which aspect of me was affected or violated? (Examples: self-esteem, pride, personal relationships, physical assets, ability to trust, emotions).

Column 4: What did I do or not do? Here you are looking for your own mistakes, if there were any, to contribute to this situation. If you were abused as a minor, state that. Children are never responsible for their abuse. If you were a victim and did not contribute to what happened, state that as well.

Column 5: Which, if any, character-defects may have played a role in this? (If you were a child, or were completely innocent as an adult, just state that). Examples of "Character Defects" are: Selfish, Self-Seeking, Dishonest, Fearful, Inconsiderate, Withdrawn, Withholding, Stubborn, Lust, Negativity, Playing God, Controlling, Revenge, Prideful, Anger, Insecurity, Guilt, Needy, Self-Pity, Perfectionism, Irresponsible, Broken Word, Denial and Delusion, Compulsive, Impulsive, Greed, Jealous, Abusive. (Fill in anything that I left out here)

Helpful Tip: A Personal Inventory is about growth, moving forward and honest self-appraisal. If you are inclined toward self-blame and feel overcome by self-punishment, I suggest that you reach out for support. There is no growth or transformation in self-deprecation (Tables 2,3)

\begin{tabular}{|c|c|c|c|c|}
\hline Column 1 & Column 2 & Column 3 & Column 4 & Column 5 \\
\hline $\begin{array}{c}\text { Who did I } \\
\text { hurt? }\end{array}$ & $\begin{array}{c}\text { What did } \\
\text { I do, or } \\
\text { not do, } \\
\text { say or not } \\
\text { say? }\end{array}$ & $\begin{array}{c}\text { Which part } \\
\text { of me } \\
\text { caused me } \\
\text { to behave in } \\
\text { this way? }\end{array}$ & $\begin{array}{c}\text { How did } \\
\text { my actions } \\
\text { effect } \\
\text { others? } \\
\text { What } \\
\text { would have } \\
\text { been the } \\
\text { ideal action } \\
\text { to take } \\
\text { instead? }\end{array}$ & $\begin{array}{c}\text { Was there } \\
\text { a } \\
\text { character } \\
\text { defect that } \\
\text { played a } \\
\text { role here? } \\
\text { Which } \\
\text { one (s)? }\end{array}$ \\
\hline & & & & \\
\hline & & & & \\
\hline
\end{tabular}

Table 2: Sample Inventory for Harms other than sexual

\section{A Word on Fear}

Fear is one of the four primal human emotions: fear, love, anger and joy. Fear can be a gift that warns you of danger or a real problem that requires a solution. Fear can also be your own self-crafted illusion. Fear gets its supremacy to the extent that you avoid facing or feeling it It also maintains its influence over you to the exact degree that you run away from it. Fear is often a gift because it reveals information that you need for your safety and security; fear can also be debilitating. Looking within is scary--the blindfold (your defenses) is there for a reason. It is advisable to go slowly and unveil only what you can handle without re-triggering trauma. The goal of writing a Fear Inventory is to inquire into the role of fear in your life: What are your specific fears? Why do you have these fears? How are they related to your resentments or dependency needs? And finally, are you willing to transform your fears into a trust for an Infinite Creator and pray for guidance on what your Creator would have you be (opposite of your fears)?

\begin{tabular}{|c|c|c|c|c|}
\hline Column 1 & Column 2 & Column 3 & Column 4 & Column 5 \\
\hline $\begin{array}{c}\text { Who did I } \\
\text { hurt? }\end{array}$ & $\begin{array}{c}\text { What did } \\
\text { I do, or } \\
\text { not do, } \\
\text { say or not } \\
\text { say? }\end{array}$ & $\begin{array}{c}\text { Which part } \\
\text { of me } \\
\text { caused me } \\
\text { to behave in } \\
\text { this way? }\end{array}$ & $\begin{array}{c}\text { How did } \\
\text { my actions } \\
\text { effect } \\
\text { others? } \\
\text { What } \\
\text { would have } \\
\text { been the } \\
\text { ideal action } \\
\text { to take } \\
\text { instead? }\end{array}$ & $\begin{array}{c}\text { Was there } \\
\text { a } \\
\text { character } \\
\text { defect that } \\
\text { played a } \\
\text { role here? } \\
\text { Which } \\
\text { one (s)? }\end{array}$ \\
\hline & & & & \\
\hline & & & & \\
\hline \multicolumn{5}{|c|}{ Table 3: Sample Sex Conduct Inventory } \\
\hline
\end{tabular}

\section{Post-Inventory Follow-Up}

Resentment, as previously described, is when you remember an incident and you feel anger. You can imagine a red flag going up every time you are having resentment. After you do a Personal Inventory about it, you can test to see if you still have resentment. Think about it and notice if the Red Flag of Resentment is either up or down. I do not want to falsely present a Personal Inventory as a magic pill that will erase resentments. However, there is something very powerful about getting your hurt, shame, guilt, fears, harms done to others, and commitments for amendments, out on paper and reviewing it in a systematic and analytical way, with the intent for spiritual transformation. Sometimes a shift in perspective can occur just by letting out the pain and grief. There are some things that will always be a sore point, and no amount of inventorying will make a difference. That is okay. The point is to get out the anger in a way that is safe, organized and concrete.

\section{Conclusion}

Dr. Hippolyte Bernheim was the physician who initially used the word psychotherapy, and, for him, psychotherapy was a process of wakeful suggestion. Dr. Bernheim espoused that a wakeful suggestion is suggesting information in a particular state of consciousness so that this information can transform the patient's baseline thoughts. And as a consequence, this transforms behavior and physiology. Writing out, analyzing, and applying the knowledge and insights from your personal inventory, is an exciting challenge to accomplish your own wakeful suggestion.

\section{References}

1. Anonymous. Alcoholics Anonymous (3rd edn) Alcoholics Anonymous World Services, Inc, (1976) New York.

2. Anonymous. Twelve Steps and Twelve Traditions, Alcoholics Anonymous World Services, Inc, (1981) New York.

3. Deventer J, Wagner J, Lüdtke $\mathrm{O}$ and Trautwein U. Are personality traits and relationship characteristics reciprocally related? Longitudinal analyses of codevelopment in the transition out of high school and beyond (2018) J Pers Soc Psychol. https://doi.org/10.1037/pspp0000191 
4. Deniz ME and Satici SA. The Relationships between Big Five Personality Traits and Subjective Vitality (2017) Annals of Psychol 33: 218-224. https://doi.org/10.6018/analesps.33.2.261911

5. Edery R. Recovery from Narcissistic Abuse through a Spiritual Lens: Who is in Charge? (2017) J Psyi Psychiatric Dis 244-251. https://doi.org/10.26502/jppd.2572-519X0023

6. Edery R. The 12 Steps of Alcoholics Anonymous as an Adjunctive Treatment for Trauma Survivors: An Experimental Approach (2014) Int J Emergency Ment Healt 16: 120.

7. Edery R. Trauma and Transformation: A 12-Step Guide (2013) New York.

8. Hippolyte Bernheim. Suggestive Therapeutics; a Treatise on the Nature and Uses of Hypnotism Hardcover (2015) Andesite Press.

9. Hippolyte Bernheim. Suggestive therapeutics: a treatise on the nature and uses of hypnotism (1919) Br Med J 2: 401.
10. Huprich SK. Reclaiming the Value of Assessing Unconscious and Subjective Psychological Experience (2011) J Pers Assess 93: 151-160. https://doi.org/10.1080/00223891.2010.542531

11. Kapustin SA. An existential criterion of normal and abnormal personality in the works of Carl Jung and Carl Rogers (2016) Psychology in Russia: State of Art 9: 54-68. https://doi.org/10.11621/pir.2015.0301

12. Martin J. Carl Rogers' and B F Skinner's approaches to personal and societal improvement: A study in the psychological humanities (2017) J Theoretical Philosophical Psychol 37: 214229. http://dx.doi.org/10.1037/teo0000072

13. Pilarska A. Contributions of Cognitive-Motivational Factors to the Sense of Identity (2017) Current Psychol 3: 468. https://doi.org/10.1007/s12144-016-9435-1 